\title{
The nonpeptide ANG-(1-7) mimic AVE 0991 attenuates cardiac remodeling and improves baroreflex sensitivity in renovascular hypertensive rats
}

\author{
Thelma Maria Bedeti Cunha a,b, Wanderson Geraldo Lima ${ }^{\mathrm{a}, \mathrm{b}}$, Marcelo Eustáquio Silva ${ }^{\mathrm{b}}$, \\ Robson Augusto Souza Santos ' ${ }^{\text {, }}$, Maria José Campagnole-Santos ${ }^{\mathrm{c}}$, Andréia Carvalho Alzamora ${ }^{\mathrm{a}, \mathrm{b}, *}$ \\ a Departamento de Ciências Biológicas, Instituto de Ciências Exatas e Biológicas, Universidade Federal de Ouro Preto, Ouro Preto, MG, Brazil \\ b Núcleo de Pesquisa em Ciências Biológicas, Universidade Federal de Ouro Preto, Ouro Preto, MG, Brazil

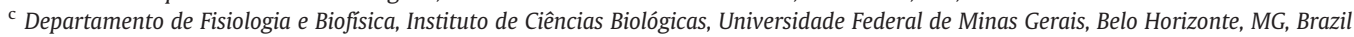

\section{A R T I C L E I N F O}

\section{Article history:}

Received 12 June 2012

Accepted 21 December 2012

\section{Keywords:}

AVE 0991

Angiotensin-(1-7)

Hypertension

Baroreflex sensitivity

Cardiac remodeling

\begin{abstract}
A B S T R A C T
Aims: The nonpeptide Ang-(1-7) analog, AVE 0991, is recognized as having beneficial cardiovascular effects similar to those induced by Ang-(1-7). In this study, we evaluated the effects of AVE 0991 on cardiovascular functions and on cardiac and renal remodeling in rats with $2 \mathrm{~K} 1 \mathrm{C}$ renovascular hypertension.

Main methods: Fisher rats underwent surgery to induce 2K1C renovascular hypertension and were then treated with AVE 0991 ( 1 or $3 \mathrm{mg} / \mathrm{kg}$ ) for 28 days. At the end of treatment, the blood pressure (BP), heart rate (HR), and baroreflex sensitivity were evaluated, in conscious animals. The rats were then euthanized and the heart and kidneys removed for subsequent histological analysis.

Key findings: Treatment with AVE 0991 in 2K1C rats restored the baroreflex sensitivity of both bradycardic and tachycardic components to levels comparable to those of normotensive SHAM rats. At a higher dose ( $3 \mathrm{mg} / \mathrm{kg}$ ), AVE 0991 was also anti-hypertensive in 2K1C rats. Furthermore, AVE 0991 reduced the heart weight, thickness of myocardial fibers, number of inflammatory cells, and area of collagen deposition in the hearts of $2 \mathrm{~K} 1 \mathrm{C}$ rats compared to SHAM rats. The inflammatory process and tissue area of collagen deposition were decreased in the clipped kidney of AVE 0091-treated 2K1C rats.

Significance: Our data showed that oral treatment with AVE 0991 reduces blood-pressure cardiac remodeling and improves baroreflex sensitivity in $2 \mathrm{~K} 1 \mathrm{C}$ renovascular hypertensive rats.
\end{abstract}

(c) 2013 Elsevier Inc. All rights reserved.

\section{Introduction}

Hypertension is characterized by increased activity of the sympathetic nervous system and overactivity of the renin angiotensin system (RAS), accompanied by reduced sensitivity of baroreflex control of arterial pressure (Korner et al., 1974; McCubbin et al., 1956), cardiac hypertrophy and remodeling, and renal lesion (Frohlich et al., 1999; Grobe et al., 2006; Sadjadi et al., 2005a,b).

Cardiac hypertrophy when accompanied by fibrosis may lead to loss of function (Frohlich et al., 1999; Grobe et al., 2006; Schaper, 1998). In addition to affecting cardiac function, hypertension may cause kidney damage, compromising the blood vessels, glomeruli and renal interstitium, causing fibrosis and loss of renal function (Klag et al., 1996; Ljutić and Kes, 2003; Soares et al., 2011). The hyperactivity of some components of the RAS is important in determining the progression of this disease. Angiotensin (Ang) II participates in cardiac remodeling by stimulating myocyte hypertrophy

\footnotetext{
* Corresponding author at: Departamento de Ciências Biológicas, Universidade Federal de Ouro Preto, Morro do Cruzeiro, 35 400-000, Ouro Preto, MG, Brazil. Tel.: +55 313559 1693; fax: + 553135591633 .

E-mail address: andreiaalzamora@iceb.ufop.br (A.C. Alzamora).
}

and fibroblast proliferation (González et al., 2002; Kawano et al. 2000). Conversely, the antitrophic and antifibrotic activity of Ang(1-7) counteracts these effects (Grobe et al., 2007; Pei et al., 2010; Tallant et al., 2005).

Loot et al. (2002) found that in rats with heart failure, chronic treatment with Ang-(1-7) preserved cardiac function, coronary perfusion and aortic endothelial function. Iwata et al. (2005) demonstrated that in cardiac fibroblasts of adult rats, Ang-(1-7) inhibited collagen synthesis and decreased mRNA expression of growth factors, suggesting an important role of Ang-(1-7) in the regulation of cardiac remodeling. Additionally, Grobe et al. (2007) showed that chronic infusion of Ang-(1-7) prevented myocardial cell hypertrophy of the left ventricle (LV) and interstitial fibrosis induced by infusion of Ang II; and Pei et al. (2010) showed that treatment with Ang-(1-7) in SHR attenuated cardiac hypertrophy and deposition of collagen during hypertensive states.

The renovascular hypertension two-kidney one-clip (2K1C) model is characterized by a hyperactivity of the RAS. In this model, the levels of Ang II increase in both kidneys, clipped and unclipped, thereby increasing plasma levels of Ang II, aldosterone and sympathetic tone, and consequently the blood pressure (BP) (Navar et al., 1998; Von Thun et al., 1994; Zou et al., 1996). Additionally, renal 
production of Ang II modulates the transport of salt and water by the renal tubules as well as the glomerular filtration process and collagen deposition (Ferrario and Varagic, 2010).

An important advance in studies of the effects of Ang-(1-7) was the discovery of non-peptide analog AVE 0991 (Wiemer et al., 2002). Several studies have shown that AVE 0991 acts as a Mas receptor agonist in the kidneys and blood vessels. AVE 0991 also induces release of nitric oxide (Lemos et al., 2005; Santos and Ferreira, 2006) and has a cardioprotective effect by improving cardiac function, reducing atherosclerosis, cardiac hypertrophy and remodeling (Benter et al., 2006; Ferreira et al., 2007b; Wiemer et al., 2002). In addition, recent studies have shown that treatment with AVE 0991 prevented myocardial hypertrophy induced by Ang II (He et al., 2010) and attenuated ventricular remodeling in rats with myocardial infarction (Zeng et al., 2012) through inhibition of inflammatory markers such as signaling TGF- $\beta 1 /$ TNF- $\alpha$ and TGF- $\beta 1 / \operatorname{Smad} 2$.

Given these considerations, this study evaluated the effect of chronic administration of AVE 0991 on BP, HR, sensitivity of the reflex control of HR, cardiac remodeling and renal injury in conscious rats with $2 \mathrm{~K} 1 \mathrm{C}$ renovascular hypertension.

\section{Materials and methods}

\section{Animals}

Experiments were performed on male Fisher rats from ENUT, Universidade Federal de Ouro Preto, Brazil. The animals were housed in separate cages in groups of four (2K1C or SHAM), with free access to rat chow and tap water in a temperature- and light-controlled room. All animal procedures were in accordance with the Guidelines for Ethical Care of Experimental Animals, and were performed as approved by the Institutional Ethics Committee of the Federal University of Ouro Preto (Protocol \# 2010/55).

\section{Induction of renovascular hypertension}

Goldblatt renovascular hypertension was induced as described by Goldblatt et al. (1934). Briefly, the rats (weighing 150-180 g) were anesthetized with a mixture of ketamine and xylazine $(50 \mathrm{mg} / \mathrm{kg}$ and $10 \mathrm{mg} / \mathrm{kg}$ respectively, ip), and a silver clip (0.20 mm ID) was placed around the left renal artery through a midline incision (Goldblatt renovascular hypertension, 2-kidney, 1-clip model; 2K1C). Other rats were submitted to similar procedures but without the renal-artery clip placement (SHAM group or normotensive rats). Cardiovascular and histological measurements were carried out 30 days after the surgery.

\section{Arterial pressure measurements}

$2 \mathrm{~K} 1 \mathrm{C}$ and SHAM rats were anesthetized with a mixture of ketamine and xylazine ( $50 \mathrm{mg} / \mathrm{kg}$ and $10 \mathrm{mg} / \mathrm{kg}$ respectively, $i p$ ) and a polyethylene catheter was inserted into the abdominal aorta through the femoral artery, for arterial pressure measurement, and another catheter was inserted into the inferior cava vein through the femoral vein, for drug injections in order to evaluate the baroreflex sensitivity. Pulsatile arterial pressure was monitored by a Gould pressure transducer (PM-1000, CWE) coupled to a blood pressure signal amplifier (UIM100A, Powerlab System). Mean arterial pressure (MAP) and heart rate (HR) were determined from the arterial pressure wave. All variables were continuously recorded with a PowerLab digital acquisition system (PowerLab 4/20, ADInstruments) with an $800 \mathrm{~Hz}$ sampling rate.

\section{Intragastric treatment with AVE 0991 or vehicle}

Three days after the surgery to induce $2 \mathrm{~K} 1 \mathrm{C}$ or SHAM, intragastric administration of AVE 0991 at a dose of $1 \mathrm{mg} / \mathrm{kg}$ or $3 \mathrm{mg} / \mathrm{kg}$, or of the Vehicle (KOH, $1 \mathrm{ml}$ of $10 \mathrm{mM} \mathrm{KOH}$ added to $9 \mathrm{ml}$ of distilled water) by gavage was started and continued daily for 28 days, always at the same time of day. The animals received around $0.2 \mathrm{ml}$ solution of AVE 0991 ( 1 or $3 \mathrm{mg} / \mathrm{kg}$ ) or vehicle.

\section{Evaluation of baroreflex sensitivity}

The sensitivity of the baroreflex control of HR was determined by recording reflex HR changes in response to transient increases (baroreflex bradycardia) or decreases (baroreflex tachycardia) in MAP produced by repeated bolus injections of graded doses of phenylephrine $(0.5$ to $50.0 \mu \mathrm{g}$, iv) or sodium nitroprusside ( 0.5 to $50.0 \mu \mathrm{g}$, iv), respectively, in conscious rats. Evaluations of the sensitivity of reflex bradycardia or tachycardia were performed randomly, with a 15-min interval between them. The HR was converted to pulse interval (PI, ms) by the formula: 60,000/HR. A best-fit regression line was drawn from MAP and HR changes obtained with the different doses of phenylephrine or sodium nitroprusside for each animal. The slope of the regression line was used as an index of baroreflex sensitivity (baroreflex gain), as in previous studies (Alzamora et al., 2006).

\section{Analysis of cardiac and renal structures}

For the histopathological analysis, hearts and kidneys were collected and fixed in 10\% neutral-buffered formalin solution. After $72 \mathrm{~h}$ of fixation, the hearts and kidneys were dehydrated, cleared, and embedded in paraffin. The paraffin block was cut into $4-5-\mu \mathrm{m}$
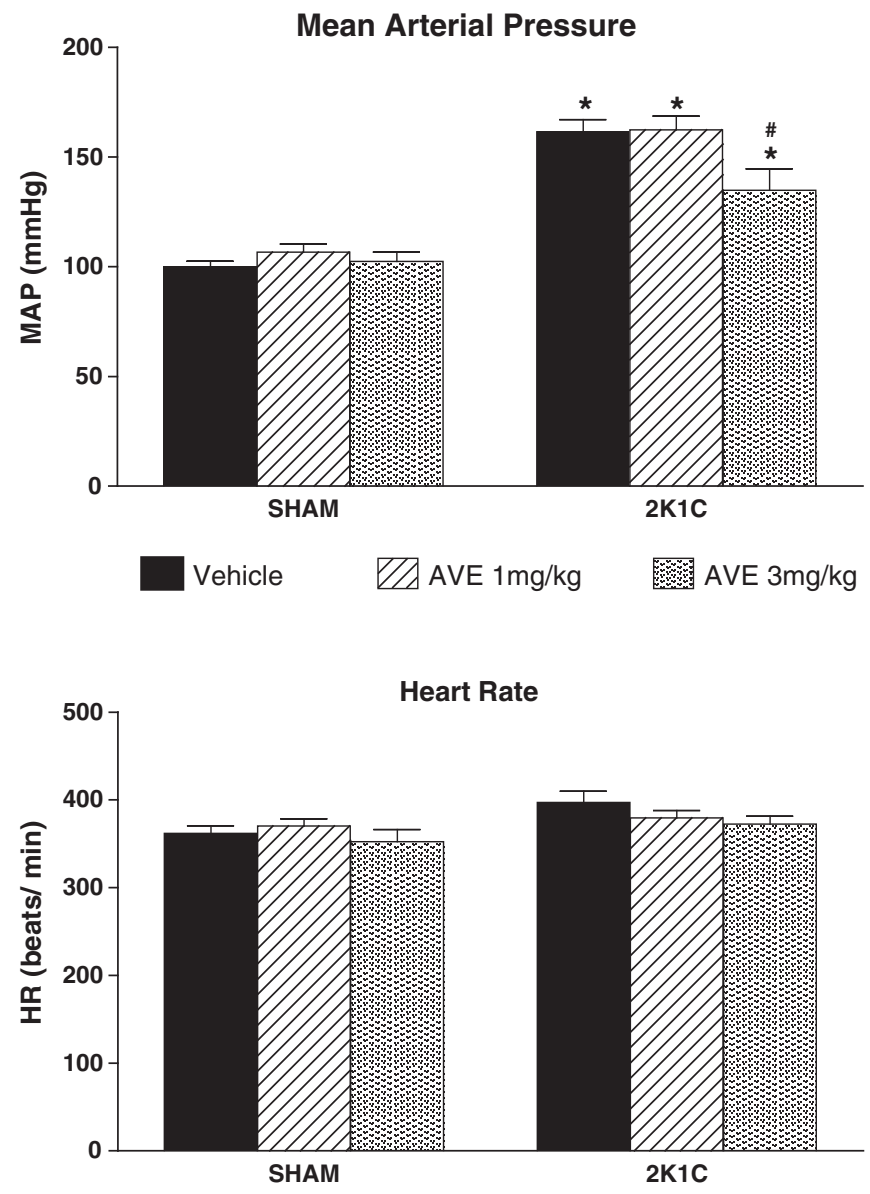

Fig. 1. Baseline levels of mean arterial pressure (MAP, $\mathrm{mm} \mathrm{Hg}$ ) and heart rate (HR, beats/minute) in normotensive rats (SHAM, $n=5-7$ ) and hypertensive rats (2K1C, $\mathrm{n}=7-9)$ treated, per gavage, for 28 days with vehicle or AVE $0991(1.0 \mathrm{mg} / \mathrm{kg}$ or AVE $3.0 \mathrm{mg} / \mathrm{kg}$ ). ${ }^{*} \mathrm{p}<0.05$ compared to SHAM vehicle group; ${ }^{\#} \mathrm{p}<0.05$ compared to 2K1C vehicle group (two-way ANOVA, followed by Bonferroni). 


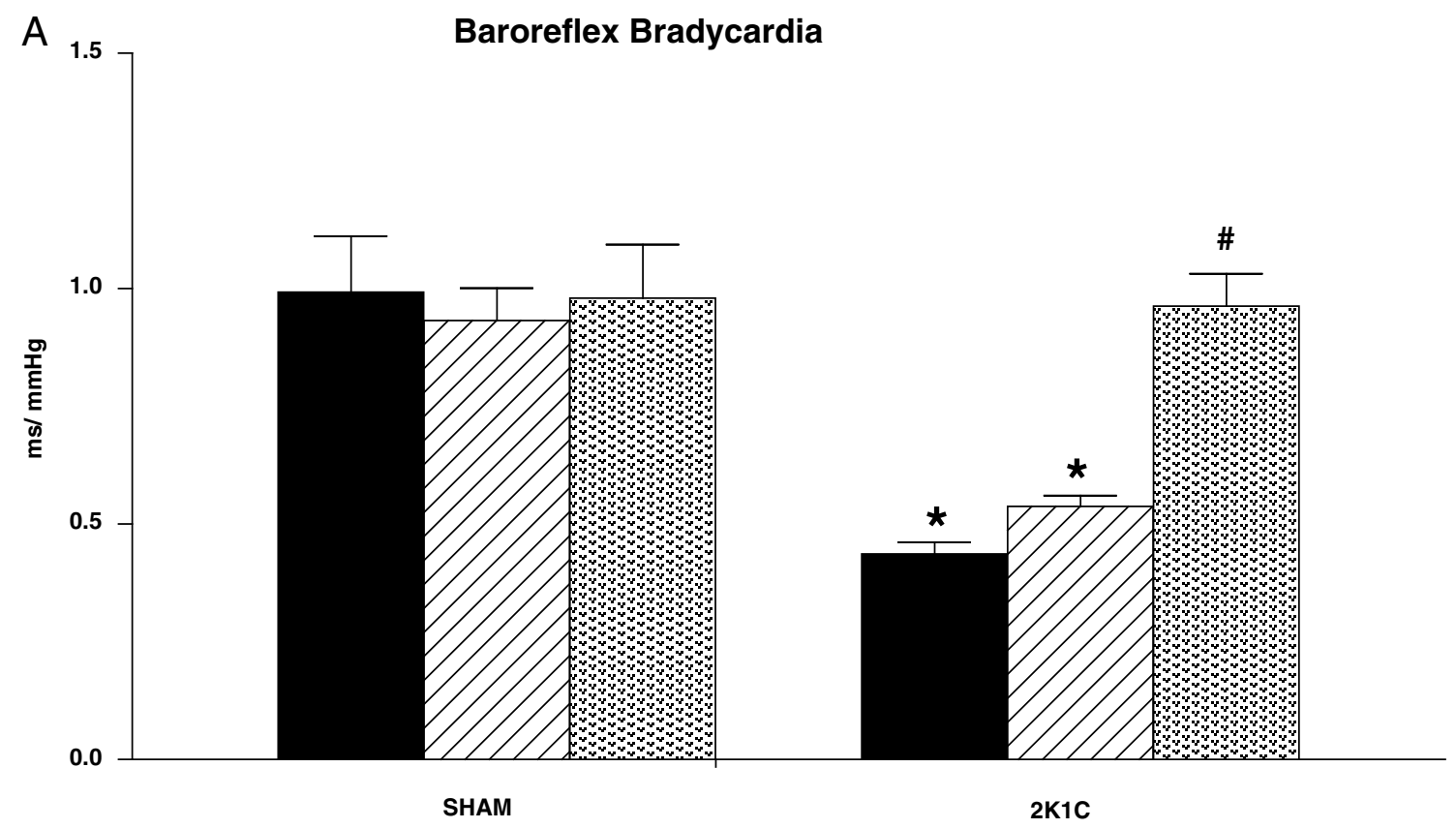

Vehicle VIIA AVE $1 \mathrm{mg} / \mathrm{kg}$ AVE $3 \mathrm{mg} / \mathrm{kg}$

B

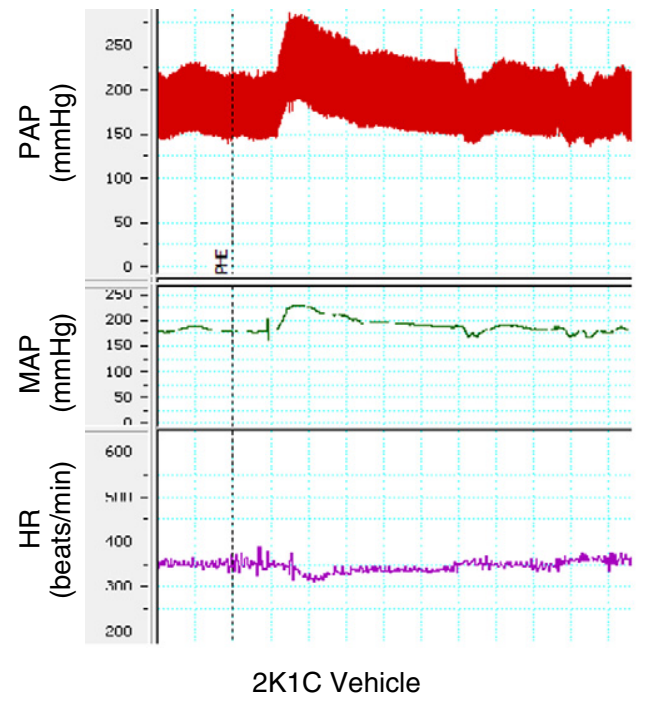

C

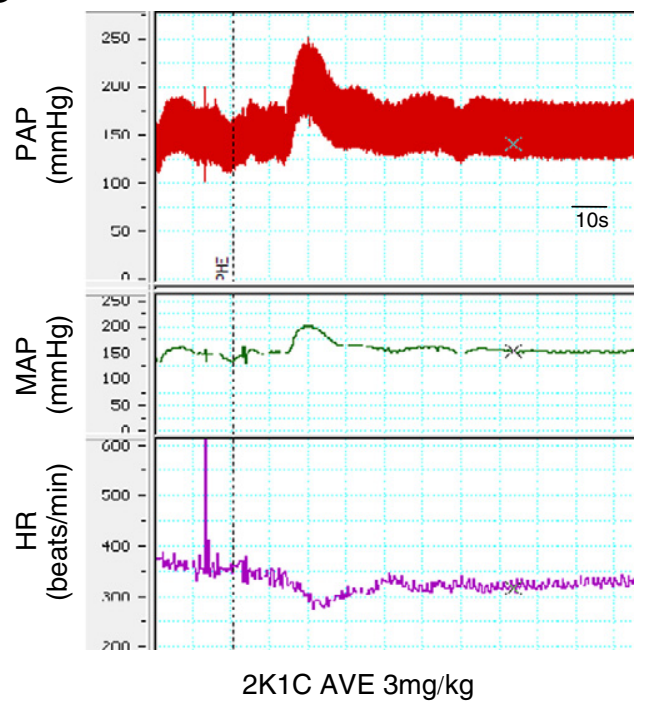

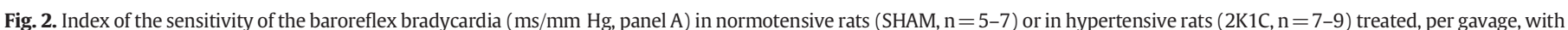

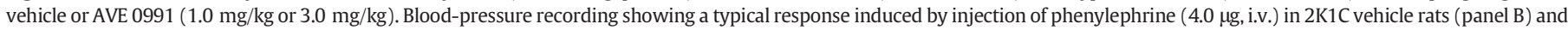

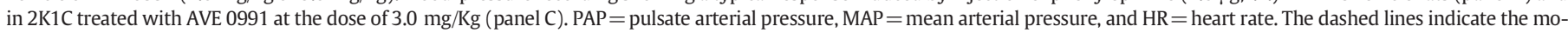
ment of the injection of phenylephrine. ${ }^{*} \mathrm{p}<0.05$ compared to SHAM groups. ${ }^{*} \mathrm{p}<0.05$ compared to $2 \mathrm{~K} 1 \mathrm{C}$ vehicle group (two-way ANOVA, followed by Bonferroni).

thick sections, and adjacent sections were stained with hematoxylin/ eosin for evaluation of general myocardial and renal damage, or by Masson's trichrome for quantification of collagen-tissue deposition. Morphometric evaluations were made in tissue sections under an optical microscope (Leica DM5000) and analyzed with the Leica Qwin Image Processing and Analysis Software (Germany). In hearts, the cardiomyocyte diameter was measured by the method described by Caliari et al. (2002) and Soares et al. (2011) in 20 optical-microscope images at $40 \times$ magnification. For hearts and kidneys, the cardiac and renal inflammatory process and tissue collagen deposition were also quantified, as described by Soares et al. (2011).
Drugs

AVE 0991 was generously donated by Dr. Juergen Puenter from Aventis Pharma; KOH (85\% potassium hydroxide ACS from Reagen, Paraná, Brazil).

\section{Statistical analysis}

The results are expressed as means \pm SEM. The data were analyzed for Kolmogorov-Smirnov normality and followed standard normal distribution; they were subsequently assessed by two-way ANOVA, 
A

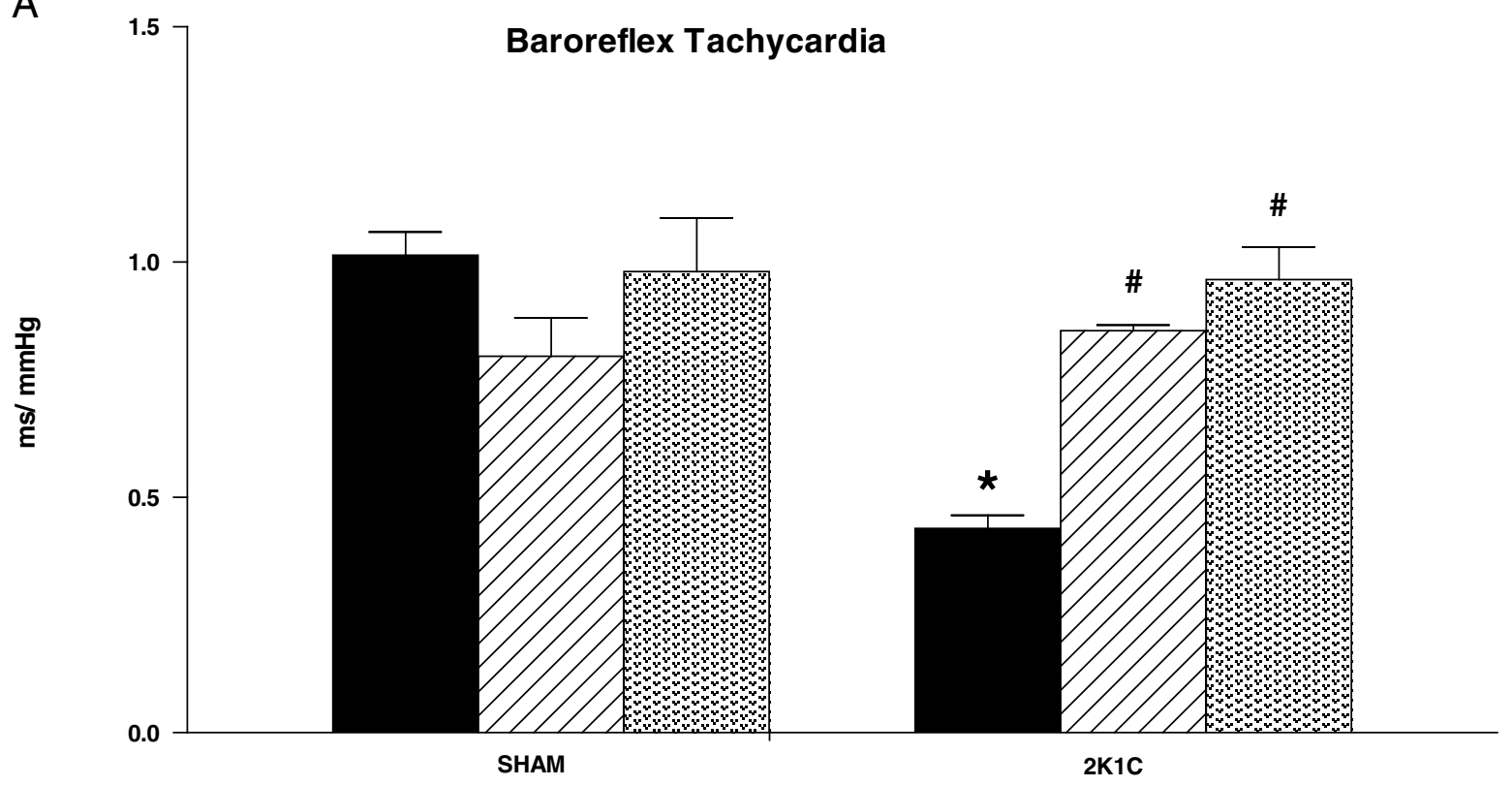

Vehicle VIIA AVE $1 \mathrm{mg} / \mathrm{Kg}$

AVE 3mg/kg

B

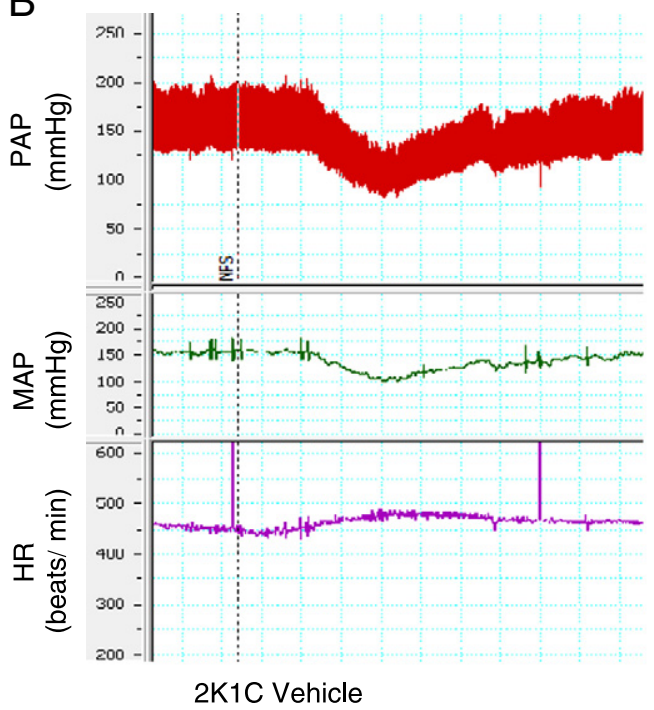

C

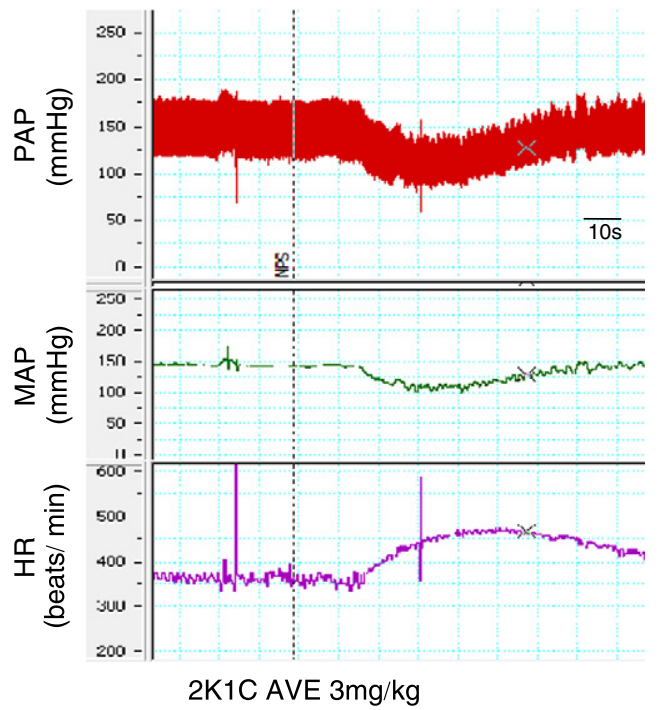

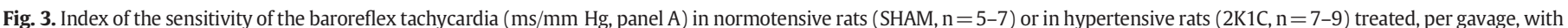

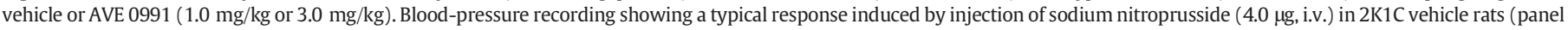

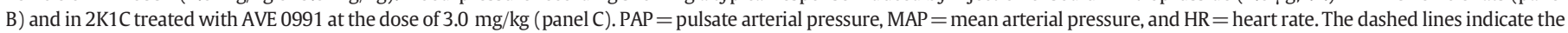
moment of injection of sodium nitroprusside. ${ }^{*} \mathrm{p}<0.05$ compared to SHAM groups. ${ }^{*} \mathrm{p}<0.05$ compared to $2 \mathrm{~K} 1 \mathrm{C}$ vehicle group (two-way ANOVA, followed by Bonferroni).

followed by the Bonferroni post-test. Statistical analyses were performed with the software GraphPad Prism (version 5.0, San Diego, USA). The criterion for statistical significance was set at $\mathrm{p}<0.05$.

\section{Results}

Baseline MAP and HR levels

The baseline MAP level for all $2 \mathrm{~K} 1 \mathrm{C}$ vehicle rats $(160 \pm 5 \mathrm{~mm} \mathrm{Hg}$, $\mathrm{n}=14)$ was higher $(\mathrm{p}<0.05)$ than the baseline MAP of all SHAM vehicle rats $(100 \pm 3 \mathrm{~mm} \mathrm{Hg}, \mathrm{n}=12)$. The $2 \mathrm{~K} 1 \mathrm{C}$ AVE $1 \mathrm{mg} / \mathrm{kg}$ rats $(\mathrm{n}=7)$ also had a higher baseline MAP $(\mathrm{p}<0.05)$ than the SHAM vehicle group $(n=6)$, and similar to that of the $2 \mathrm{~K} 1 \mathrm{C}$ vehicle rats $(n=7)(p>0.05)$ (Fig. 1). However, in the treatment with AVE $3 \mathrm{mg} / \mathrm{kg}$, the baseline MAP of $2 \mathrm{~K} 1 \mathrm{C} \mathrm{AVE} 3 \mathrm{mg} / \mathrm{kg}$ rats $(\mathrm{n}=9)$ was lower $(p<0.05)$ than the MAP of 2 K1C vehicle rats $(n=7)$, but the baseline MAP of $2 \mathrm{~K} 1 \mathrm{C}$ AVE $3 \mathrm{mg} / \mathrm{kg}$ rats was higher $(\mathrm{p}<0.05)$ than the baseline MAP of the SHAM vehicle group $(n=6)$ (Fig. 1$)$. The treatment with AVE in doses of 1 and $3 \mathrm{mg} / \mathrm{kg}$ did not alter the baseline MAP levels of SHAM rats $(n=5-7)$ compared to SHAM vehicle 

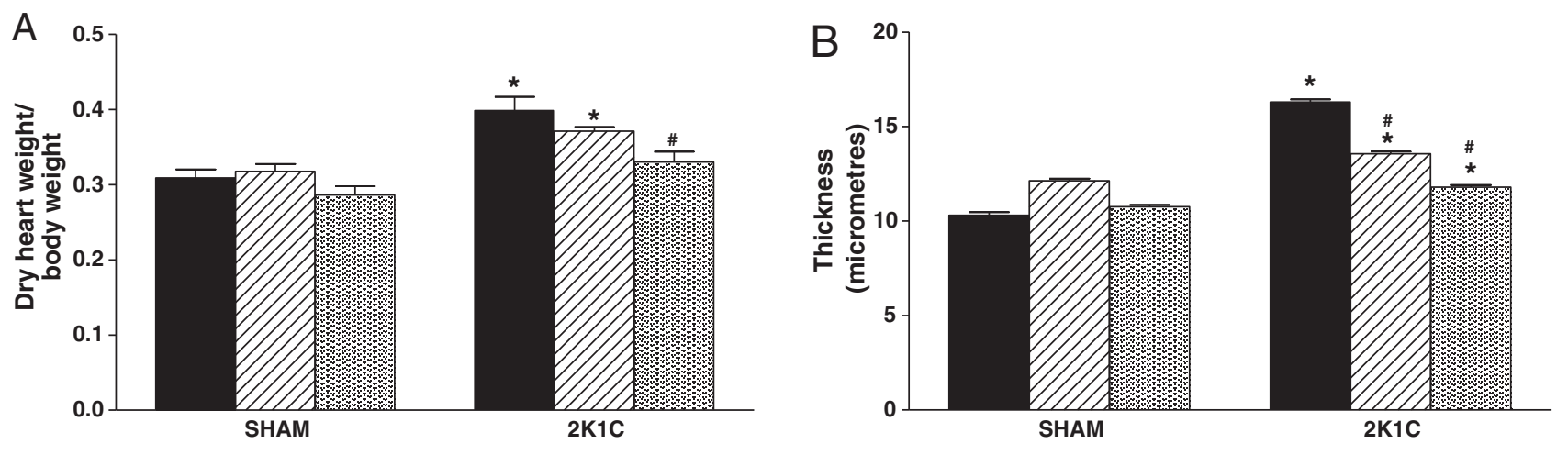

Vehicle

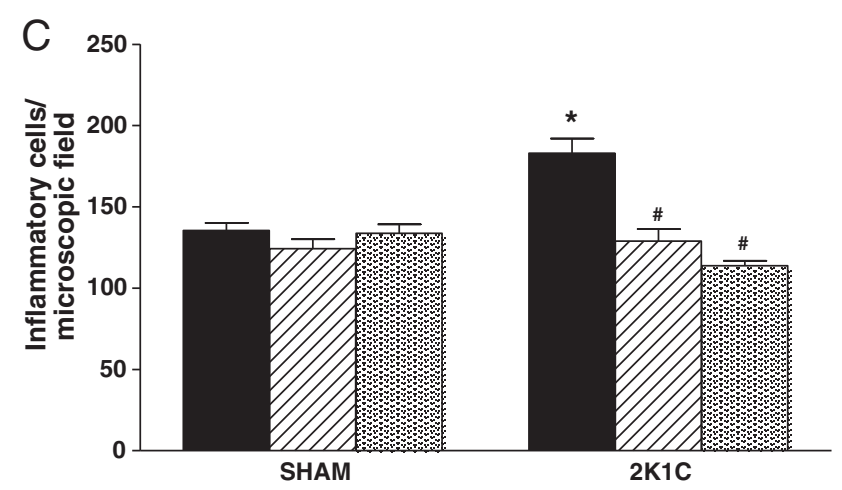

AVE $1 \mathrm{mg} / \mathrm{Kg} \quad \because \mathrm{AVE} 3 \mathrm{mg} / \mathrm{kg}$

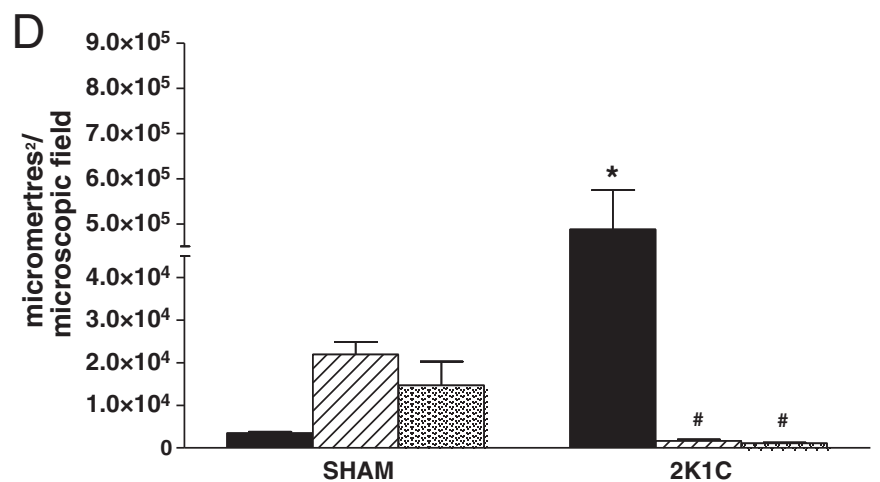

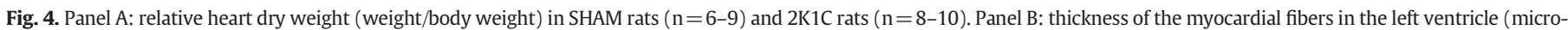

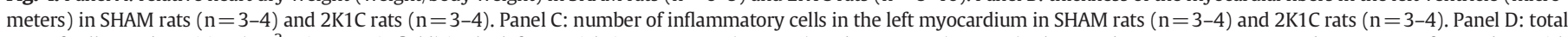

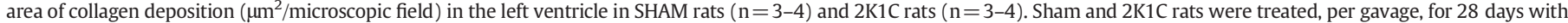
AVE 0991 ( $1.0 \mathrm{mg} / \mathrm{kg}$ or $3.0 \mathrm{mg} / \mathrm{kg}$ ) or vehicle. * $\mathrm{p}<0.05$ compared to SHAM group. ${ }^{*} \mathrm{p}<0.05$ compared to the $2 \mathrm{~K} 1 \mathrm{C}$ vehicle group (two-way ANOVA, followed by Bonferroni).

animals $(n=6)$ (Fig. 1). Baseline HR levels did not differ between the 2K1C or SHAM groups treated with vehicle or AVE 0991 at doses of $1 \mathrm{mg} / \mathrm{kg}$ or $3 \mathrm{mg} / \mathrm{kg}$ (Fig. 1).

\section{Evaluation of baroreflex sensitivity}

As expected, the sensitivity of reflex bradycardia in all $2 \mathrm{~K} 1 \mathrm{C}$ vehicle animals $(0.58 \pm 0.14 \mathrm{~ms} / \mathrm{mm} \mathrm{Hg}, \mathrm{n}=14)$ was lower $(\mathrm{p}<0.05)$ than the sensitivity of reflex bradycardia in all SHAM vehicle animals $(1.03 \pm 0.05 \mathrm{~ms} / \mathrm{mm} \mathrm{Hg}, \mathrm{n}=12)$. Regarding the treatment with AVE $1 \mathrm{mg} / \mathrm{kg}$, the sensitivity of reflex bradycardia in 2K1C AVE $1 \mathrm{mg} / \mathrm{kg}$ $(n=7)$ was lower $(p<0.05)$ than the reflex bradycardia in the SHAM vehicle group $(n=6)$ (Fig. 2A). Furthermore, the hypertensive 2K1C vehicle animals $(n=7)$ and 2K1C AVE $1 \mathrm{mg} / \mathrm{kg}(\mathrm{n}=7)$ showed similar levels of the sensitivity of reflex bradycardia ( $p>0.05$ ) (Fig. 2A). The bradycardiac component of the reflex control of HR in SHAM rats treated with AVE 1 or $3 \mathrm{mg} / \mathrm{kg}$ was similar ( $p>0.05$ ) to the reflex bradycardia of SHAM rats (Fig. 2A). However, animals treated with 2K1C AVE $3 \mathrm{mg} / \mathrm{kg}(\mathrm{n}=9)$ had a higher sensitivity of reflex bradycardia $(\mathrm{p}<0.05)$ compared to $2 \mathrm{~K} 1 \mathrm{C}$ vehicle rats $(\mathrm{n}=8)$, and similar $(\mathrm{p}>0.05)$ to that of the SHAM vehicle rats (Fig. 2A, B and C).

The sensitivity of the reflex tachycardia in all $2 \mathrm{~K} 1 \mathrm{C}$ vehicle animals $(0.54 \pm 0.012 \mathrm{~ms} / \mathrm{mm} \mathrm{Hg}, \mathrm{n}=15)$ was lower $(\mathrm{p}<0.05)$ than the sensitivity of reflex tachycardia in the SHAM vehicle group $(1.01 \pm$ $0.04 \mathrm{~ms} / \mathrm{mm} \mathrm{Hg}, \mathrm{n}=12$ ). Treatments with AVE in doses of 1 and $3 \mathrm{mg} / \mathrm{kg}$ improved the sensitivity of the reflex tachycardia in rats with $2 \mathrm{~K} 1 \mathrm{C}$ hypertension. The 2K1C AVE $1 \mathrm{mg} / \mathrm{kg}$ animals $(\mathrm{n}=7)$ were similar $(p>0.05)$ to the SHAM AVE $1 \mathrm{mg} / \mathrm{kg}$ group $(n=5)$ and higher $(\mathrm{p}<0.05)$ than the $2 \mathrm{~K} 1 \mathrm{C}$ vehicle group (Fig. $3 \mathrm{~A})$. Likewise, the $2 \mathrm{~K} 1 \mathrm{C}$ AVE $3 \mathrm{mg} / \mathrm{kg}$ group $(\mathrm{n}=9)$ showed similar levels of sensitivity reflex tachycardia $(\mathrm{p}<0.05)$ to those of the SHAM vehicle group $(n=6)$, and higher $(p<0.05)$ than the $2 \mathrm{~K} 1 \mathrm{C}$ vehicle group $(\mathrm{n}=8)$ (Fig. 3A, B and C).

Our data also showed that baseline levels of BP correlated inversely with the sensitivity of the reflex control of HR (AVE $1 \mathrm{mg} / \mathrm{kg}$, $\mathrm{r}=-0.9527$ and AVE $3 \mathrm{mg} / \mathrm{kg}, \mathrm{r}=-0.8804$ ).

\section{Analysis of cardiac structure}

Morphological effects of intragastric administration of AVE 0991 in rats with renovascular hypertension were evaluated morphometrically in cardiac tissue. Renovascular hypertension increased the $(\mathrm{p}<0.05)$ cardiac weight in all $2 \mathrm{~K} 1 \mathrm{C}$ groups, compared with non-hypertensive animals (SHAM groups). Moreover, 2K1C AVE $09913.0 \mathrm{mg} / \mathrm{kg}$ rats had a lower cardiac weight $(\mathrm{p}<0.05)$ than 2K1C vehicle and 2K1C AVE $09911.0 \mathrm{mg} / \mathrm{kg}$ rats (Fig. 4A). The cardiomyocyte diameter increased $(\mathrm{p}<0.05)$ in all 2K1C (vehicle or AVE 0991) groups compared with SHAM rats. Again, 2K1C vehicle rats showed an increase $(\mathrm{p}<0.05)$ in cardiomyocyte diameter compared with 2K1C AVE $09911.0 \mathrm{mg} / \mathrm{kg}$ and AVE $09913.0 \mathrm{mg} / \mathrm{kg}$ rats (Fig. 4B). Intragastric administration of AVE 0991 prevented the increase of inflammatory cells $(\mathrm{p}<0.05)$ in $2 \mathrm{~K} 1 \mathrm{C}$ AVE $1.0 \mathrm{mg} / \mathrm{kg}$ and 2K1C AVE $3.0 \mathrm{mg} / \mathrm{kg}$ compared with 2R1C VEHICLE rats (Figs. 4C and 5$)$. The collagen deposition area also increased $(p<0.05)$ in 


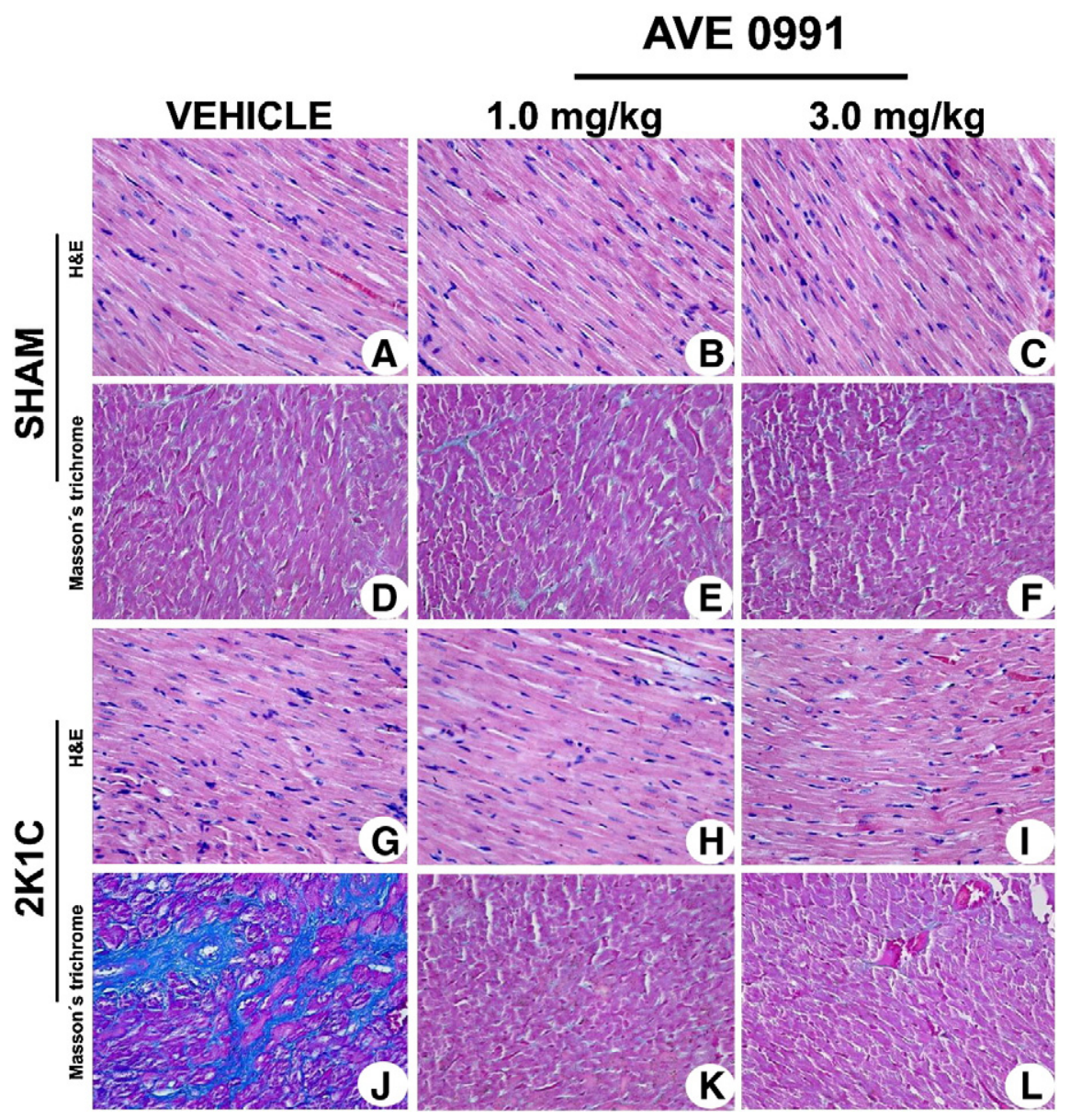

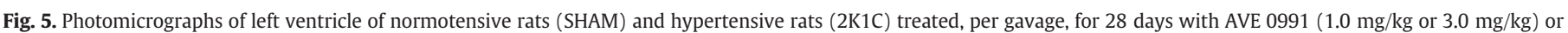

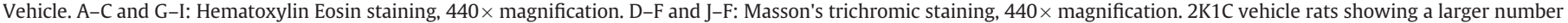

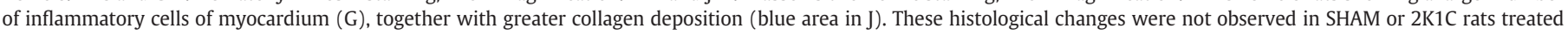
with AVE 0991.

2K1C vehicle rats over 2K1C AVE $09911.0 \mathrm{mg} / \mathrm{kg}$, 2K1C AVE 0991 $3.0 \mathrm{mg} / \mathrm{kg}\left(1082 \pm 164 \mu \mathrm{m}^{2}, \mathrm{p}<0.05\right)$ or SHAM groups (Figs. 4D and 5).

\section{Analysis of renal structure}

The histopathological changes in the right (non-clipped) and left (clipped) kidneys were determined by morphometric analysis. In the right kidney, renovascular hypertension caused an increase $(\mathrm{p}<0.05)$ of inflammatory cells in 2K1C vehicle, 2K1C AVE 0991 $1.0 \mathrm{mg} / \mathrm{kg}$ and in 2K1C AVE $09913.0 \mathrm{mg} / \mathrm{kg}$ compared with the SHAM groups (Figs. 6A and 7). Moreover, no effects of renovascular hypertension or intragastric administration of AVE 0991 on collagentissue area were observed in the right kidney (Figs. 6B and 7).

Clipped kidneys also showed an increase $(\mathrm{p}<0.05)$ of inflammatory cells in 2K1C vehicle, 2K1C AVE $09911.0 \mathrm{mg} / \mathrm{kg}$ and in 2K1C AVE $09913.0 \mathrm{mg} / \mathrm{kg}$ rats compared with SHAM groups (Figs. 6C and 7). The collagen-tissue area increased $(\mathrm{p}<0.05)$ in $2 \mathrm{~K} 1 \mathrm{C}$ vehicle rats compared with SHAM groups, 2K1C AVE $09911.0 \mathrm{mg} / \mathrm{kg}$ and 2K1C AVE $09913.0 \mathrm{mg} / \mathrm{kg}$ rats. In addition, the collagen-tissue area in 2K1C AVE $09911.0 \mathrm{mg} / \mathrm{kg}$ and in 2K1C AVE $09913.0 \mathrm{mg} / \mathrm{kg}$ was similar to that in the SHAM groups (Figs. 6D and 7).

\section{Discussion}

The results of this study showed that an orally active Mas receptor agonist, AVE 0991, was effective in preventing different parameters that are altered in $2 \mathrm{~K} 1 \mathrm{C}$ renovascular hypertension. In summary, four weeks of treatment with AVE 0991 improved the sensitivity of the baroreflex control of HR, and reduced the diameter of cardiomyocytes, the number of inflammatory cells, and cardiac fibrosis in $2 \mathrm{~K} 1 \mathrm{C}$ hypertensive rats. Furthermore, AVE 0991 decreased the number of inflammatory cells and fibrosis in the clipped kidney. Our data also showed that treatment with AVE 0991, at a dose of $3 \mathrm{mg} / \mathrm{kg}$, induced a hypotensive effect in 2K1C hypertensive rats. There was no effect of AVE 0991 on baseline BP in normotensive SHAM rats. Together, the data from this study showed renoprotective and cardioprotective effects induced by treatment with AVE 0991 during development of $2 \mathrm{~K} 1 \mathrm{C}$ renovascular hypertension.

It is well established that Ang-(1-7) exerts important effects related to the tonic or reflex regulation of BP (Benter et al., 1995; Ferrario, 2003; Santos et al., 2000) and has antitrophic and antifibrotic effects (Santos et al., 2003; Tallant et al., 2005). The discovery of AVE 0991 (Wiemer et al., 2002) as a biologically active compound, resistant to gastric enzymes and showing effects similar to those of Ang-(1-7), made it possible to explore the role of Ang-(1-7) in different pathologies such as cardiovascular diseases. Studies on normotensive animals have shown that short-term treatment with AVE 0991 ( $1 \mathrm{mg} / \mathrm{kg}$; for 7 or 4 weeks) did not change baseline BP and HR in rats subjected to isoproterenol-induced cardiac hypertrophy and dysfunction (Ferreira et al., 2007a) or in rats that underwent left coronary ligation (Zeng et al., 2012). In keeping with these observations, our present results showed that treatment with AVE 09911 or $3 \mathrm{mg} / \mathrm{kg}$ did not alter the 
Right Kidney
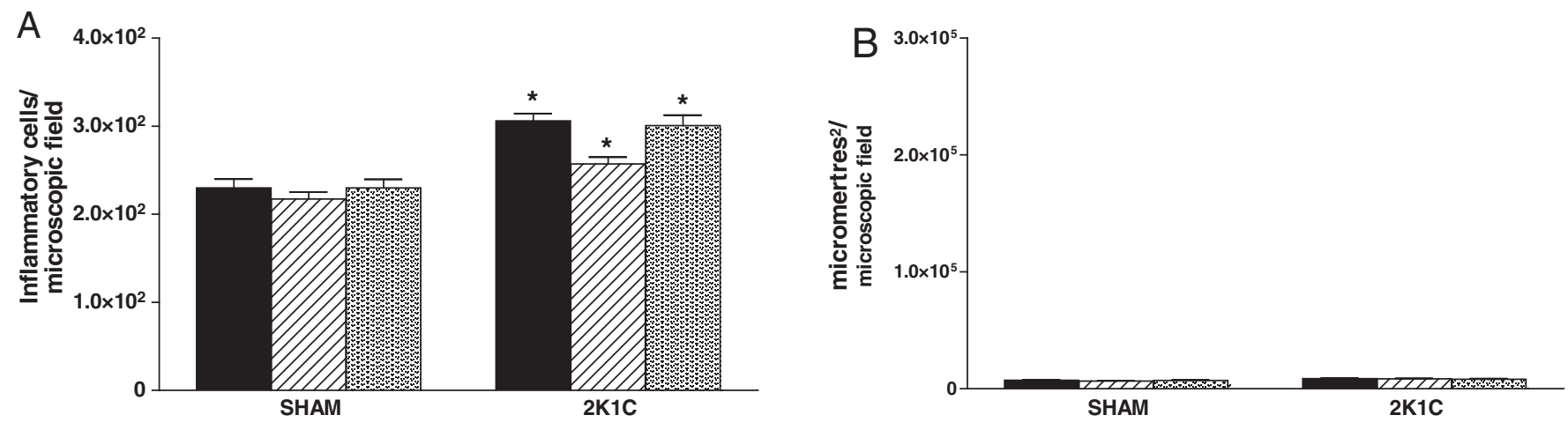

Vehicle

QIIIA AVE $1 \mathrm{mg} / \mathrm{Kg}$

AVE 3mg/kg

Left Kidney
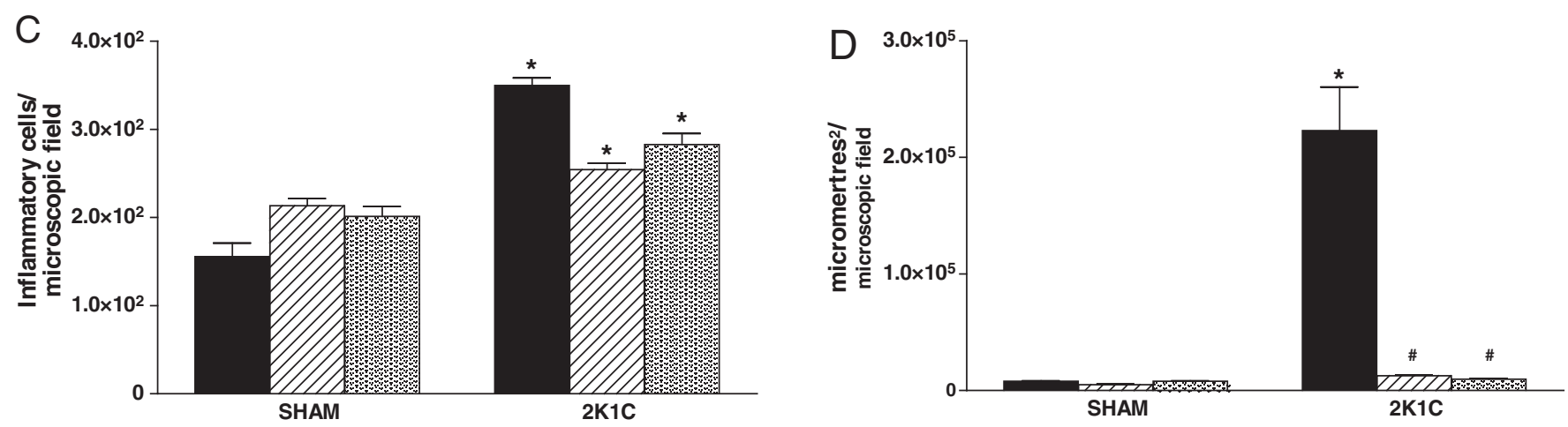

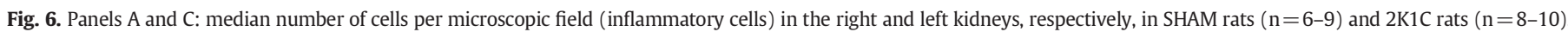

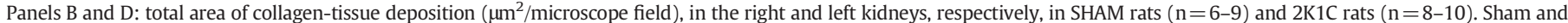

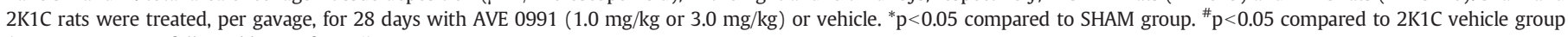
(two-way ANOVA, followed by Bonferroni).

baseline BP in normotensive SHAM rats. In addition, our data also showed that treatment with AVE $09911 \mathrm{mg} / \mathrm{kg}$ dose did not alter the baseline $\mathrm{BP}$ in $2 \mathrm{~K} 1 \mathrm{C}$ hypertensive rats.

Moreover, Benter et al. (2006) showed that Ang-(1-7) and AVE 0991 prevented, but did not abolish the L-NAME hypertension induced in SHR. Similarly, our results showed that treatment with AVE 0991 at a dose of $3 \mathrm{mg} / \mathrm{kg}$ reduced the baseline levels of BP in 2K1C rats. Reductions in baseline levels of BP are considered important to reduce cardiac afterload and consequently the development of cardiac hypertrophy, and to reduce endothelial and kidney dysfunctions (Hammond and Janes, 1998; Savage et al., 1979).

The reduced sensitivity of baroreflex control of HR is considered to be a risk factor for the development of LV hypertrophy, heart failure and sudden death (Fei et al., 1994; Piratello et al., 2010). There is a consensus, both for animals and for human patients, that hypertension is accompanied by attenuation of baroreflex sensitivity (Korner et al., 1974; McCubbin et al., 1956). Furthermore, our data showed that baseline levels of BP correlated inversely with the sensitivity of the reflex control of HR. Accordingly, only the treatment with AVE 0991 at a dose of $3 \mathrm{mg} / \mathrm{kg}$ induced a fall on baseline BP in 2K1C hypertensive that was sufficient to improve both baroreflex bradycardia and tachycardia. In addition, the treatment with AVE 0991 at a dose of $1 \mathrm{mg} / \mathrm{kg}$, which did not reduce the baseline BP of 2K1C rats, did not induce improvement in sensitivity of the reflex bradycardia.

Ang II and Ang-(1-7) have opposite effects on the control of the baroreflex in normotensive (Campagnole-Santos et al., 1992; Ferrario et al., 1997; Polson et al., 2007) and hypertensive rats (Benter et al., 1995; Britto et al., 1997; Chaves et al., 2000; Heringer-Walther et al., 2001). While Ang II reduces baroreflex sensitivity (Casto and Phillips, 1985; Head, 1996), Ang-(1-7) induces a facilitation of the baroreflex, after both peripheral administration (Santos et al., 2000) and intracerebroventricular (ICV) administration (Campagnole-Santos et al., 1992). In addition, Benter et al. (1995) showed in SHR infused with Ang-(1-7) that there was an improvement in sensitivity of the reflex control of heart rate to levels similar to untreated WKY. Britto et al. (1997) showed that ICV infusion of the selective antagonist of Ang-(1-7), A-779 produces attenuation of the baroreflex control of HR in 2K1C renovascular hypertensive rats subjected to chronic treatment with enalapril (ACE inhibitor), suggesting that part of the beneficial effect induced by ACE inhibition may be related to effects of Ang-(1-7) on the CNS. Later, Heringer-Walther et al. (2001) suggested 


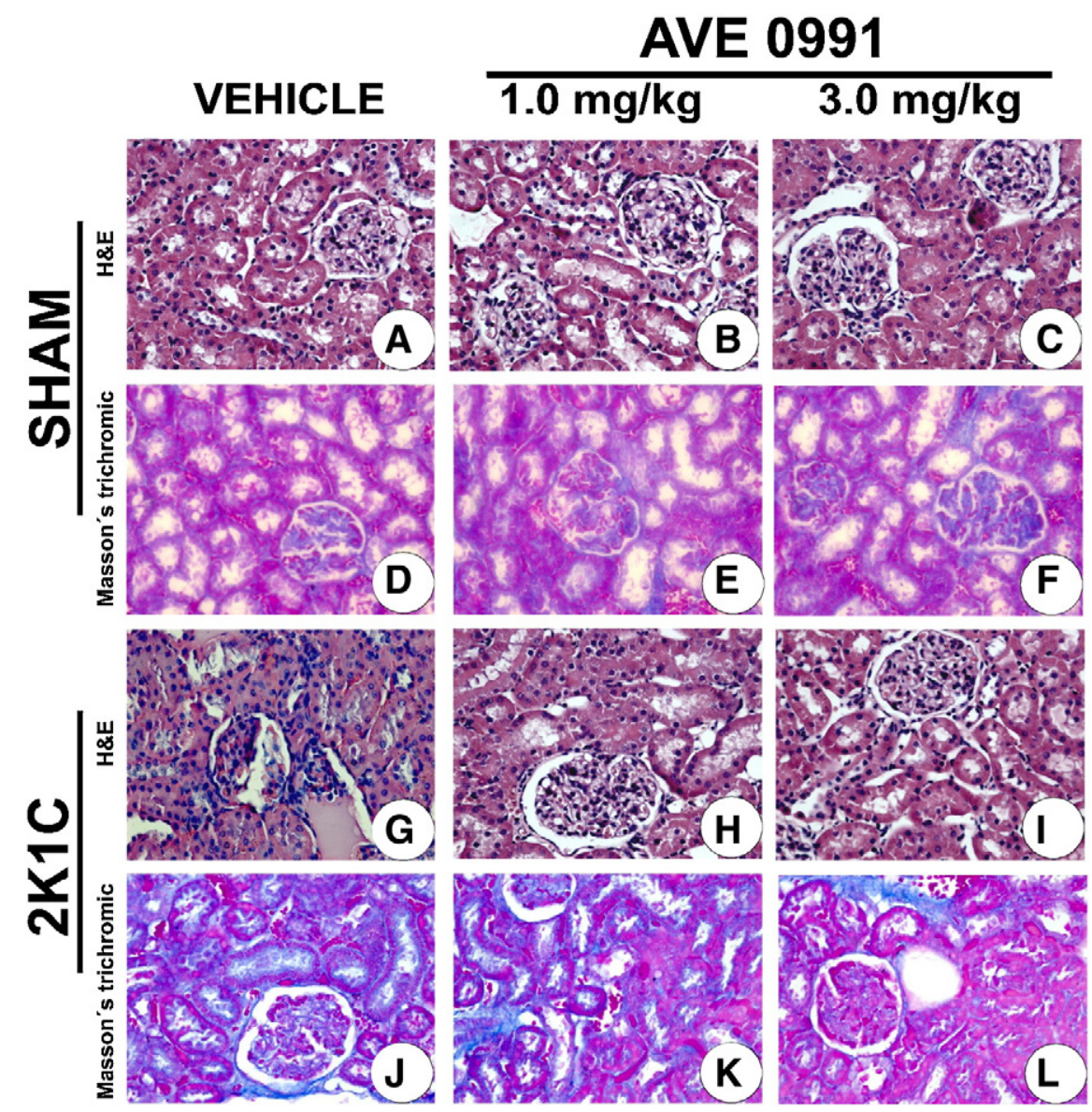

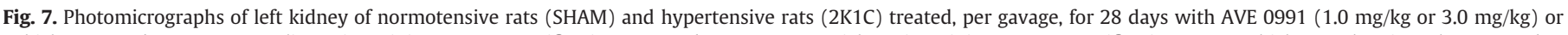

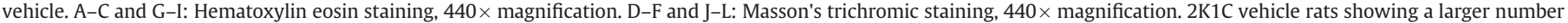
of inflammatory cells $(G)$ together with greater collagen deposition (blue area in J). This histological change was not observed in SHAM or 2K1C rats treated with AVE 0991.

that Ang-(1-7) is involved in the improvement of reflex bradycardia sensitivity in SHR after ICV infusion of an ACE inhibitor (ramipril). In concordance with these findings, our present data showed that treatment with AVE 0991 improved baroreflex sensitivity in 2K1C hypertensive rats, similar to that described for Ang-(1-7). Further studies will be necessary to determine whether the rise in baroreflex control induced by AVE 0991 is due to peripheral or central elements of the baroreceptor circuitry.

A methodological aspect to be considered in the interpretation of our results is related to the sodium nitroprusside used to evaluate the baroreflex sensitivity of the tachycardia. According to Musialek and Casadei (2000), the nitrovasodilators, nitric-oxide donors, have extra-vascular effects that may interfere with the evaluation of reflex control of HR. The increase in HR induced by sodium nitroprusside may not be directly due to changes in transmission of baroreflex and autonomic nervous-system activity (Musialek and Casadei, 2000). The literature is controversial, but a possible interference relates to a positive chronotropic effect, independent of changes in BP (Casadei and Paterson, 2000; Hogan et al., 1999; Musialek and Casadei, 2000). As already mentioned, it has been reported that the AVE 0991 acts by releasing nitric oxide (Wiemer et al., 2002), allowing a probable interaction with sodium nitroprusside, which may explain the improvement in sensitivity of the reflex control of HR for the tachycardic component at both doses of AVE 0991.

Previous studies showed that Ang-(1-7) can be synthesized in the heart (Zisman et al., 2003) and that this heptapeptide has beneficial effects by reducing cardiac remodeling and attenuating the development of cardiac arrhythmias (Grobe et al., 2006; Tallant et al., 2005; Trask and Ferrario, 2007). In our present study, the mean dry weight of the heart of 2K1C animals treated with AVE 0991 ( $3 \mathrm{mg} / \mathrm{kg}$ ) was lower than that of $2 \mathrm{~K} 1 \mathrm{C}$ or $2 \mathrm{~K} 1 \mathrm{C}$ treated with $1 \mathrm{mg} / \mathrm{kg}$ AVE. However, AVE 0991 induced a reduction in the thickness of myocardial fibers of the LV in 2K1C rats at both 1 and $3 \mathrm{mg} / \mathrm{kg}$ doses. In addition, treatment with AVE 0991 at both doses reduced the number of inflammatory cells in the heart of $2 \mathrm{~K} 1 \mathrm{C}$ rats. Treatment with both doses of AVE 0991 significantly reduced collagen deposition in the heart of $2 \mathrm{~K} 1 \mathrm{C}$ rats, reinforcing an antifibrotic and antitrophic effect induced by AVE 0991.

Benter et al. (2006) showed that AVE and Ang-(1-7) were equipotent in reducing cardiac hypertrophy and cardiac collagen deposition in SHR rats treated with the nitric oxide synthase inhibitor, L-NAME. Ferreira et al. (2007a) showed that treatment with AVE 0991 ( $1 \mathrm{mg} / \mathrm{kg} /$ week) during the development of heart failure reduced the size of the infarcted area. In another study, Ferreira et al. (2007b) showed that treatment with AVE $0991(1 \mathrm{mg} / \mathrm{kg})$ for 7 days in a model of cardiac dysfunction induced by isoproterenol, reduced the weight of the heart, collagen deposition and the diameter of the cardiomyocytes. Our data advanced these observations by showing that AVE 0991 reduced the number of inflammatory cells, collagen deposition and the diameter of cardiomyocytes in $2 \mathrm{~K} 1 \mathrm{C}$ rats.

$2 \mathrm{~K} 1 \mathrm{C}$ renovascular hypertension is characterized by hyperactivity of the RAS (Ferrario and Varagic, 2010; Pinheiro et al., 2009). The clipped kidney, due to reduction of renal blood flow, loses weight, while the unclipped contralateral kidney increases its weight and 
size, probably due to a compensatory hyperfunction (Navar et al., 1995; Navar et al., 1998; Rodrigues et al., 2007). Collagen deposition increases only in the clipped kidney (Soares et al., 2011). Recently, Prieto et al. (2011) evaluated the component of RAS axes [ACE, ACE2, Ang II and Ang-(1-7)] in cortical and medullary regions of both kidneys, clipped and unclipped, in 2K1C hypertensive rats (three weeks after clipping). The levels of Ang II and Ang I increased, while the levels of Ang-(1-7) decreased in both kidneys. However, Ang II levels were higher in the clipped compared to the unclipped kidney. Moreover, in both kidneys the levels of ACE mRNA increased, while ACE2 mRNA levels decreased. These alterations in RAS enzymes probably contribute to change the content of intrarenal RAS peptides, favoring the accumulation of Ang II. This concords with the increase in the number of inflammatory cells and collagen deposition in the clipped kidney of $2 \mathrm{~K} 1 \mathrm{C}$ rats in our present study. Our results also showed that treatment with both doses of AVE 0991 reduced the number of inflammatory cells and collagen deposition in the clipped kidney. Our data concord with those of Pinheiro et al. (2009), who showed an increase in the expression of collagen and fibronectin in the kidney of mice with genetic deletion of the Mas receptor, suggesting that the decreased levels of Ang-(1-7) or a lack of its effect, combined with increased levels of Ang II, may induce prefibrotic lesion in the kidney. Furthermore, our data showed that treatment with AVE 0991 was effective in preventing the inflammatory effect and deposition of collagen in the clipped kidney, probably by an opposition to the high levels of Ang II.

Importantly, the anti-inflammatory and anti-prefibrotic lesions in the heart and kidney were observed with both doses of AVE 0991, even at the dose of $1 \mathrm{mg} / \mathrm{kg}$ which did not change the level of hypertension. These data indicate a direct effect, independent of BP alteration, of the Mas receptor agonist AVE 0991 in attenuating kidney and cardiac fibrosis induced by hypertension.

\section{Conclusion}

The data from the present study extend previous observations by showing that AVE 0991, an orally active nonpeptide Ang-(1-7) mimic, can attenuate the deleterious effects induced by chronic increase in Ang II on the blood pressure, baroreflex control, and in heart and kidney fibrosis. Futher, our data showed that treatment with AVE 0991 has a direct antitrophic and antifibrotic effect on the heart and kidney in the $2 \mathrm{~K} 1 \mathrm{C}$ renovascular hypertension model.

\section{Conflict of Interest}

None of the authors has a conflict of interest.

\section{Acknowledgments}

This study was supported by FAPEMIG-RedeToxifar (Fundação de Amparo à Pesquisa do Estado de Minas Gerais), CNPq (Conselho Nacional de Desenvolvimento Científico e Tecnológico), INCTNanobiofar-FAPEMIG-CNPq, Pronex Project Grant (FAPEMIG/CNPq) and CAPES (Coordenação de Aperfeiçoamento de Pessoal de Nível Superior). Thelma Maria Bedeti Cunha received a DTI-3-573924/2008-2-INCTNano-Biofarmacêutica-FAPEMIG-CNPq fellowship (Master's Degree).

\section{References}

Alzamora AC, Santos RA, Campagnole-Santos MJ. Baroreflex modulation by angiotensins at the rat rostral and caudal ventrolateral medulla. Am J Physiol 2006;290:R1027-34.

Benter IF, Diz DI, Ferrario CM. Pressor and reflex sensitivity is altered in spontaneously hypertensive rats treated with angiotensin-(1-7). Hypertension 1995;26:1138-44.

Benter IF, Yousif MH, Anim JT, Cojocel C, Diz DI. Angiotensin-(1-7) prevents development of severe hypertension and end-organ damage in spontaneously hypertensive rats treated with L-NAME. Am J Physiol Heart Circ Physiol 2006;290:H684-91.
Britto RR, Santos RA, Fagundes-Moura CR, Khosla MC, Campagnole-Santos MJ. Role of angiotensin-(1-7) in the modulation of the baroreflex in renovascular hypertensive rats. Hypertension 1997;30:549-56.

Caliari MV, de Lana M, Cajá RA, Carneiro CM, Bahia MT, Santos CA, et al. Immunohistochemical studies in acute and chronic canine chagasic cardiomyopathy. Virchows Arch 2002;441:69-76.

Campagnole-Santos MJ, Heringer SB, Batista EN, Khosla MC, Santos RA. Differential baroreceptor reflex modulation by centrally infused angiotensin peptides. Am J Physiol 1992;263:R89-94.

Casadei B, Paterson DJ. Should we still use nitrovasodilators to test baroreflex sensitivity? J Hypertens 2000;18:3-6.

Casto R, Phillips MI. Neuropeptide action in nucleus tractus solitarius: angiotensin specificity and hypertensive rats. Am J Physiol 1985;249:R341-7.

Chaves GZ, Caligiorne SM, Santos RA, Khosla MC, Campagnole-Santos MJ. Modulation of the baroreflex control of heart rate by angiotensin-(1-7) at the nucleus tractus solitarii of normotensive and spontaneously hypertensive rats. J Hypertens 2000;18:1841-8.

Fei L, Slade AK, Grace AA, Malik M, Camm AJ, McKenna WJ. Ambulatory assessment of the QT interval in patients with hypertrophic cardiomyopathy: risk stratification and effect of low dose amiodarone. Pacing Clin Electrophysiol 1994;17: 2222-7.

Ferrario CM. Contribution of angiotensin-(1-7) to cardiovascular physiology and pathology. Curr Hypertens Rep 2003;5:129-34.

Ferrario CM, Varagic J. The ANG-(1-7)/ACE2/mas axis in the regulation of nephron function. Am J Physiol Renal Physiol 2010;298:F1297-305.

Ferrario CM, Chappell MC, Tallant EA, Brosnihan KB, Diz DI. Counterregulatory actions of angiotensin-(1-7). Hypertension 1997;30:535-41.

Ferreira AJ, Oliveira TL, Castro MC, Almeida AP, Castro CH, Caliari MV, et al Isoproterenol-induced impairment of heart function and remodeling are attenuated by the nonpeptide angiotensin-(1-7) analogue AVE 0991. Life Sci 2007a;81: 916-23.

Ferreira AJ, Jacoby BA, Araújo CA, Macedo FA, Silva GA, Almeida AP, et al. The nonpeptide angiotensin-(1-7) receptor Mas agonist AVE-0991 attenuates heart failure induced by myocardial infarction. Am J Physiol Heart Circ Physiol 2007b;292:H1113-9.

Frohlich ED, Navar LG, Re RN. Hypertension: the present years. Hypertension 1999;33: 1097-8.

Goldblatt H, Lynch J, Hanzal RF, Summerville WW. Studies on experimental hypertension: I. The production of persistent elevation of systolic blood pressure by means of renal ischemia. J Exp Med 1934;59:347-79.

González B, Negredo P, Hernando R, Manso R. Protein variants of skeletal muscle regulatory myosin light chain isoforms: prevalence in mammals, generation and transitions during muscle remodelling. Pflugers Arch 2002;443:377-86.

Grobe JL, Mecca AP, Mao H, Katovich MJ. Chronic angiotensin-(1-7) prevents cardiac fibrosis in DOCA-salt model of hypertension. Am J Physiol Heart Circ Physio 2006;290:H2417-23.

Grobe JL, Mecca AP, Lingis M, Shenoy V, Bolton TA, Machado JM, et al. Prevention of angiotensin II-induced cardiac remodeling by angiotensin-(1-7). Am J Physiol Heart Circ Physiol 2007;292:H736-42.

Hammond KA, Janes DN. The effects of increased protein intake on kidney size and function. J Exp Biol 1998;201:2081-90.

He JG, Chen SL, Huang YY, Chen YL, Dong YG, Ma H. The nonpeptide AVE0991 attenuates myocardial hypertrophy as induced by angiotensin II through downregulation of transforming growth factor-beta1/Smad2 expression. Heart Vessels 2010;25: 438-43.

Head GA. Role of AT1 receptors in the central control of sympathetic vasomotor function. Clin Exp Pharmacol Physiol 1996;23(Suppl. 3):S93-8

Heringer-Walther S, Batista EN, Walther T, Khosla MC, Santos RA, Campagnole-Santos MJ. Baroreflex improvement in shr after ace inhibition involves angiotensin-(1-7). Hypertension 2001;37:1309-14.

Hogan N, Kardos A, Paterson DJ, Casadei B. Effect of exogenous nitric oxide on baroreflex function in humans. Am J Physiol 1999;277:H221-7.

Iwata M, Cowling RT, Gurantz D, Moore C, Zhang S, Yuan JX, et al. Angiotensin-(1-7) binds to specific receptors on cardiac fibroblasts to initiate antifibrotic and antitrophic effects. Am J Physiol Heart Circ Physiol 2005;289:H2356-63.

McCubbin Jw, Green JH, PAGE IH. Baroceptor function in chronic renal hypertension. Circ Res 1956;4:205-10

Kawano H, Do YS, Kawano Y, Starnes V, Barr M, Law RE, et al. Angiotensin II has multiple profibrotic effects in human cardiac fibroblasts. Circulation 2000;101:1130-7.

Klag MJ, Whelton PK, Randall BL, Neaton JD, Brancati FL, Ford CE, et al. Blood pressure and end-stage renal disease in men. N Engl J Med 1996;334:13-8.

Korner PI, Oliver JR, Sleight P, Chalmers JP, Robinson JS. Effects of clonidine on the baroreceptor-heart rate reflex and on single aortic baroreceptor fibre discharge. Eur J Pharmacol 1974;28:189-98.

Lemos VS, Silva DM, Walther T, Alenina N, Bader M, Santos RA. The endothelium-dependent vasodilator effect of the nonpeptide Ang(1-7) mimic AVE 0991 is abolished in the aorta of mas-knockout mice. J Cardiovasc Pharmacol 2005;46:274-9.

Ljutić D, Kes P. The role of arterial hypertension in the progression of non-diabetic glomerular diseases. Nephrol Dial Transplant 2003;18(Suppl. 5):v28-30.

Loot AE, Roks AJ, Henning RH, Tio RA, Suurmeijer AJ, Boomsma F, et al. Angiotensin-(1-7) attenuates the development of heart failure after myocardial infarction in rats. Circulation 2002;105:1548-50.

Musialek P, Casadei B. Nitrovasodilators and heart rate: more than the arterial baroreflex. Cardiovasc Res 2000;47:404-5.

Navar LG, Von Thun AM, Zou L, el-Dahr SS, Mitchell KD. Enhancement of intrarenal angiotensin II levels in 2 kidney 1 clip and angiotensin II induced hypertension. Blood Press Suppl 1995;2:88-92. 
Navar LG, Zou L, Von Thun A, Tarng Wang C, Imig JD, Mitchell KD. Unraveling the mystery of Goldblatt hypertension. News Physiol Sci 1998;13:170-6.

Pei Z, Meng R, Li G, Yan G, Xu C, Zhuang Z, et al. Angiotensin-(1-7) ameliorates myocardial remodeling and interstitial fibrosis in spontaneous hypertension: role of MMPs/TIMPs. Toxicol Lett 2010;199:173-81.

Pinheiro SV, Ferreira AJ, Kitten GT, da Silveira KD, da Silva DA, Santos SH, et al. Genetic deletion of the angiotensin-(1-7) receptor Mas leads to glomerular hyperfiltration and microalbuminuria. Kidney Int 2009;75:1184-93.

Piratello AC, Moraes-Silva I, Paulini J, Souza PR, Sirvente R, Salemi V, et al. Renin angiotensin system and cardiac hypertrophy after sinoaortic denervation in rats. Clinics (Sao Paulo) 2010;65:1345-50.

Polson JW, Dampney RA, Boscan P, Pickering AE, Paton JF. Differential baroreflex control of sympathetic drive by angiotensin II in the nucleus tractus solitarii. Am J Physiol Regul Integr Comp Physiol 2007;293:R1954-60.

Prieto MC, González-Villalobos RA, Botros FT, Martin VL, Pagán J, Satou R, et al. Reciprocal changes in renal ACE/ANG II and ACE2/ANG 1-7 are associated with enhanced collecting duct renin in Goldblatt hypertensive rats. Am J Physiol Renal Physiol 2011;300:F749-55.

Rodrigues MC, Campagnole-Santos MJ, Machado RP, Silva ME, Rocha JL, Ferreira PM, et al. Evidence for a role of AT(2) receptors at the CVLM in the cardiovascular changes induced by low-intensity physical activity in renovascular hypertensive rats. Peptides 2007;28:1375-82.

Sadjadi J, Kramer GL, Yu CH, Burress Welborn M, Chappell MC, Gregory Modrall J. Angiotensin converting enzyme-independent angiotensin ii production by chymase is up-regulated in the ischemic kidney in renovascular hypertension. J Surg Res 2005a; 127:65-9.

Sadjadi J, Kramer GL, Yu CH, Welborn MB, Modrall JG. Angiotensin II exerts positive feedback on the intrarenal renin-angiotensin system by an angiotensin converting enzyme-dependent mechanism. J Surg Res 2005b;129:272-7.

Santos RA, Simoes e Silva AC, Maric C, Silva DM, Machado RP, de Buhr I, et al. Angiotensin-(1-7) is an endogenous ligand for the $G$ protein-coupled receptor Mas. Proc Natl Acad Sci U S A 2003;100:8258-63.
Santos RA, Ferreira AJ. Pharmacological effects of AVE 0991, a nonpeptide angiotensin-(1-7) receptor agonist. Cardiovasc Drug Rev 2006;24:239-46.

Santos RA, Campagnole-Santos MJ, Andrade SP. Angiotensin-(1-7): an update. Regul Pept 2000;91:45-62.

Savage DD, Drayer JI, Henry WL, Mathews EC, Ware JH, Gardin JM, et al. Echocardiographic assessment of cardiac anatomy and function in hypertensive subjects. Circulation 1979;59:623-32.

Schaper W. The regulation of gene expression in myocardial ischemia. Thorac Cardiovasc Surg 1998;46(Suppl. 2):277-80.

Soares ER, Lima WG, Machado RP, Carneiro CM, Silva ME, Rodrigues MC, et al. Cardiac and renal effects induced by different exercise workloads in renovascular hypertensive rats. Braz J Med Biol Res 2011;44:573-82.

Tallant EA, Ferrario CM, Gallagher PE. Angiotensin-(1-7) inhibits growth of cardiac myocytes through activation of the mas receptor. Am J Physiol Heart Circ Physiol 2005;289:H1560-6.

Trask AJ, Ferrario CM. Angiotensin-(1-7): pharmacology and new perspectives in cardiovascular treatments. Cardiovasc Drug Rev 2007;25:162-74.

Von Thun AM, Vari RC, el-Dahr SS, Navar LG. Augmentation of intrarenal angiotensin II levels by chronic angiotensin II infusion. Am J Physiol 1994;266:120-8.

Wiemer G, Dobrucki LW, Louka FR, Malinski T, Heitsch H. AVE 0991, a nonpeptide mimic of the effects of angiotensin-(1-7) on the endothelium. Hypertension 2002;40:847-52.

Zeng WT, Chen WY, Leng XY, Tang LL, Sun XT, Li CL, et al. Impairment of cardiac function and remodeling induced by myocardial infarction in rats are attenuated by the nonpeptide angiotensin-(1-7) analog AVE 0991. Cardiovasc Ther 2012;30:152-61.

Zisman LS, Meixell GE, Bristow MR, Canver CC. Angiotensin-(1-7) formation in the intact human heart: in vivo dependence on angiotensin II as substrate. Circulation 2003;108:1679-81.

Zou Y, Komuro I, Yamazaki T, Aikawa R, Kudoh S, Shiojima I, et al. Protein kinase C, but not tyrosine kinases or Ras, plays a critical role in angiotensin II-induced activation of Raf-1 kinase and extracellular signal-regulated protein kinases in cardiac myocytes. J Biol Chem 1996;271:33592-7. 